\title{
Pushover Analysis Pile of ULA Jacket Platform Towards Earthquake Loads by SNI-1726:2012
}

\author{
Dirta M Chameliaa, $^{\mathrm{a},}$, Alim B Prakoso ${ }^{\mathrm{b}}$ and Silvianita ${ }^{\mathrm{c}}$ \\ a) Lecturer, Department of Ocean Engineering, Institut Teknologi Sepuluh Nopember, Kampus ITS - Sukolilo, Surabaya 60111, Indonesia \\ b) Student, Department of Ocean Engineering, Institut Teknologi Sepuluh Nopember, Kampus ITS - Sukolilo, Surabaya 60111, Indonesia \\ c) Assistant Professor, Department of Ocean Engineering, Institut Teknologi Sepuluh Nopember, Kampus ITS - Sukolilo, Surabaya 60111, \\ Indonesia \\ *Corresponding author: marchad_dr@oe.its.ac.id
}

\begin{abstract}
This study aims at analyzing pushover on pile jacket structure based on SNI-1726:2012 standards for earthquake loads. Pushover analysis or ultimate strength was performed on ULA jacket platform operated by PHE ONWJ. The jacket platform is operated in the northwestern part of the Java Sea. Design of earthquake loads on ULA jacket platform structure with large seismic acceleration was obtained. From seismic analysis, dynamic response occurred on ULA jacket platform is evaluated, with natural structure period of 1.256 seconds. The largest shear base values were in $X$ and $Y$ directions resulted from seismic acceleration of $P G A$ $0.2 \mathrm{~g}$. On member check, the critical part happens to be one of the members of WD2, and on joint check, the largest UC occurred on $401 L$ joint, both were due to the aforementioned earth quake aceleration. Pushover analysis was then performed to obtain the value of RSR (Reserve Strength Ratio). The analysis yields an RSR value which far exceed the limiting criteria of API RP $2 A$ WSD of RSR $\geq$ 0.8. Therefore it could be concluded that ULA jacket platform structure is within the range of low consequence category.
\end{abstract}

Keywords: jacket platform, seismic, ultimate strength, pushover, PGA, RSR

\section{INTRODUCTION}

Generally, a fixed offshore platform consists of three main components. Firstly, the deck as the supporting structure to uphold the topside and entire operation area of the platform. Secondly, the jacket functioned as pillar to support the deck and transferring of loads both in vertical and lateral directions. Thirdly, the pile as the foundation for the jacket platform anchored in the seabed [1]. The stability of jacket platform essentially depends on the stability of the pile [2,3]. Pile is one of the important components of offshore structure, but also one of the most vulnerable component. This is because pile is closely related to the condition of the ground or seabed.
In this study, pushover on the pile of ULA jacket platform is analyzed by using API RP 2A WSD approach. $U L A$ jacket platform is a fixed offshore platform structure that serves to process oil and gas from wellhead before it is transported through the pipeline. The flow rate of $U L A$ jacket platform is 10 MMSCFD and oil production is approximately 3,000 BOPD with a 3-phase fluid with the route of pipeline $U L A$ leads to $U W$ platform. The location of $U L A$ platform is at the coordinate of $06^{\circ} 05^{\prime} 39.44^{\prime \prime}$ Latitude and $107^{\circ} 42^{\prime} 29.07^{\prime \prime}$ East Longitude, which is in the waters around North West Java Sea, as indicated in Fig. 1.

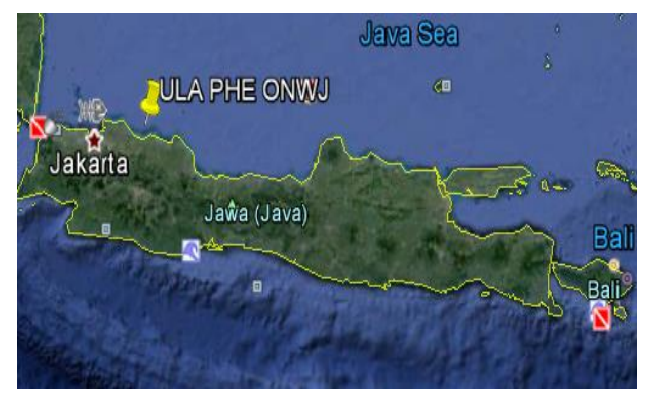

Figure 1. The location of $U L A$ jacket platform

\section{MATERIALS AND METHODS}

The flow of activities undertaken to resolve the problems of this study is commenced by literature review, carried out toward references related to this study from scientific journals, thesis and relevant sources. Further, the jacket design refers to $U L A$ jacket platform of PHE ONWJ, operated at water depth of $74.875 \mathrm{ft}$. The diameter of the jacket leg was 33 inches with five levels of bracing, namely:
1. Jacket Bracing elev. (-) $1.735 \mathrm{ft}$ (Jacket Walkway level)
2. Jacket Bracing elev. (-) $20.615 \mathrm{ft}$
3. Jacket Bracing elev. (-) $39.335 \mathrm{ft}$ 
4. Jacket Bracing elev. (-) $58.055 \mathrm{ft}$

5. Jacket Bracing elev. (-) $76.775 \mathrm{ft}$ (Mudline level)

Once the structure model is designed, as shown in Fig. 2 , the next stage is to perform an in-place analysis to validate the modeling of the data existing structure data. In-place analysis used structural analysis software. Validation was reviewed from the comparison of the structural weight data and the weight resulted from the modeling.

Table 1. Validation of structure modeling

\begin{tabular}{|c|c|c|}
\hline \multicolumn{2}{|c|}{ Weight of Structures (kips) } & \multirow{2}{*}{ Correction (\%) } \\
\hline Data & Modeling & \\
\hline 586.562 & 590.676 & 0.993 \\
\hline
\end{tabular}

In Table 1, the correction value of the structure weight does not exceed $5 \%$. Hence the result of structure modeling is considered valid and aptly represents the actual conditions.

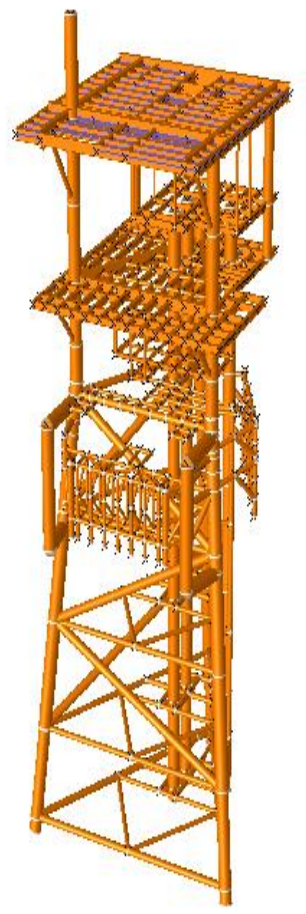

Figure 2. Results of structure modeling of overall $U L A$ jacket platform

The next stage is to determine seismic loads with SNI1726:2012 standards. In determining this earthquake loads, it is necessary to analyze the equivalent lateral force. The analysis of equivalent lateral force is the static analysis in SNI-1726:2012. The purpose of this analysis is to obtain base shear force generated by the earthquake loads which is already obtained, as described in the following.

\subsection{Establishing Building Risk Categories}

Building risk category is associated with the level of risk allowed in the planned building as intended. According to SNI-1726:2012 [4] there are four building risk category, as particularly shown in Table 2 .

Table 2. Building risk category [4]

\begin{tabular}{|c|c|}
\hline Utilization Buildings Or Structures & Risk Category \\
\hline $\begin{array}{l}\text { Building and non-building that has a low risk to human life in } \\
\text { the event of failure }\end{array}$ & I \\
\hline $\begin{array}{l}\text { All the buildings and other structures, except those belonging } \\
\text { to risk category I, III, and IV }\end{array}$ & II \\
\hline $\begin{array}{l}\text { Building and non-building that has a risk to human life in the } \\
\text { event of failure }\end{array}$ & III \\
\hline $\begin{array}{l}\text { Building and non-building, which does not include the risk } \\
\text { category IV, which has the potential to cause huge economic } \\
\text { impact and / or mass distuption to the lives of everyday } \\
\text { people in the event of failure }\end{array}$ & \\
\hline $\begin{array}{l}\text { Building and non-building that does not include risk category } \\
\text { IV, (including, but not limited to the manufacturing facility, } \\
\text { process, handling, storage, use or disposal of fuel hazardous or } \\
\text { combustible material exploded) that contain toxic materials or } \\
\text { explosives which the amount of content of the material } \\
\text { exceeding the limit values specified authorized agencies and } \\
\text { reasonably pose a danger to the public in case of leakage. }\end{array}$ & \\
\hline $\begin{array}{l}\text { Building and non-building indicated as essential facilities. } \\
\text { Building and non-building is needed to maintain the function of } \\
\text { the structure of other buildings that fall into the risk category } \\
\text { IV. }\end{array}$ & IV \\
\hline
\end{tabular}

\subsection{Determining Virtue of Earthquake Factor $I_{e}$}

$I_{e}$ value is obtained based on the risk category of a building or structure. Table 3 presents the virtue of earthquake factor $I_{e}$.

Table 3. Virtue of earthquake factors [4]

\begin{tabular}{|c|c|}
\hline Risk Category & L. \\
\hline I or II & 1.0 \\
\hline III & 1.25 \\
\hline IV & 1.5 \\
\hline
\end{tabular}

\subsection{Determining Site Classification}

The determination of seismic design criteria should be performed, particularly in the form of amplification factors for the structure. In determining amplification factors of a structure, the soil profile at the site should be determined. There are three most influential parameters in determining the classification of site:

- Average shear strength of undrained, $S_{u}$,

- Average standard field penetration resistance, $N$ (for cohesive soils), $N_{C H}$ (for non-cohesive soil),

- Average velocity of shear waves, $V_{s}$ 
The site classification can be seen in the Table 4 .

Table 4. Site classification [4]

\begin{tabular}{|c|c|c|c|}
\hline Site Class & $\mathrm{V}_{\mathrm{a}}(\mathrm{m} / \mathrm{s})$ & $\mathrm{N}$ or $\mathrm{Ner}$ & $\mathrm{S}_{4}$ \\
\hline SA (hard rock) & $>1500$ & $\mathrm{~N} / \mathrm{A}$ & $\mathrm{N} / \mathrm{A}$ \\
\hline SB (rock) & 750 to 1500 & $\mathrm{~N} / \mathrm{A}$ & $\mathrm{N} / \mathrm{A}$ \\
\hline $\begin{array}{c}\text { SC (hard soil, very dense and } \\
\text { soft rock) }\end{array}$ & 350 to 750 & $>50$ & $\geq 100$ \\
\hline SD (medium soil) & 150 to 350 & 15 to 50 & 50 to 100 \\
\hline \multirow[b]{2}{*}{ SE (soft soil) } & $<175$ & $<15$ & $<50$ \\
\hline & \multicolumn{3}{|c|}{$\begin{array}{l}\text { Or any soil containing profiles of more than } 3 m \text { ground } \\
\text { with the following characteristics: } \\
\text { 1. The plasticity index, } P I>20 \\
\text { 2. The water content, } w \geq 40 \% \\
\text { 3 niralir shear strength, } S_{u}<25 \mathrm{kPa}\end{array}$} \\
\hline $\begin{array}{l}\text { SF (special soil, which } \\
\text { requires specific geotechnical } \\
\text { investigation and analysis of } \\
\text { site-specific responses that } \\
\text { follow } 6.10 .1 \text { ) }\end{array}$ & \multicolumn{3}{|c|}{$\begin{array}{l}\text { Each layer of soil profile has one or more of the } \\
\text { following characteristics: } \\
\text { - troubled and potential failed or collapse result load } \\
\text { quake as easy liquefaction, clay very sens itive, ground } \\
\text { cemented weak } \\
\text { - Clay very organic and / or Peat (thickness } H>3 \mathrm{~m} \text { ) } \\
\text { - Clay berplastisitas, very height (thickness } H>7,5 \mathrm{~m} \\
\text { with } \\
\text { Plasticity Inndelk, } P I>75 \text { ) } \\
\text { A layer of soft clay / half firmly in thickness } H>35 \mathrm{~m} \\
\text { with } \\
\mathrm{S}_{\mathrm{u}}<50 \mathrm{kPa}\end{array}$} \\
\hline
\end{tabular}

\subsection{Determining Site Coefficient, $\boldsymbol{F}_{a}$ and $\boldsymbol{F}_{\boldsymbol{v}}$}

Site coefficient can be obtained based on the classification of the site. Tables 5 and 6 , respectively, depict the site coefficients $\mathrm{F}_{a}$ and $F_{v}$ to be implemented.

Table 5. Site coefficient, $F_{a}[4]$

\begin{tabular}{|c|c|c|c|c|c|}
\hline \multirow[t]{2}{*}{$\begin{array}{c}\text { Site } \\
\text { Classification }\end{array}$} & \multicolumn{5}{|c|}{$\begin{array}{l}\text { Parameter Spectral Response Acceleration } \\
\mathrm{MCE}_{R} \text { Earthquake in shorter periods }\end{array}$} \\
\hline & $\begin{array}{l}\text { Ss } \leq \\
0,25\end{array}$ & $\begin{array}{l}\text { Ss }= \\
0,5\end{array}$ & $\begin{array}{l}\text { Ss= } \\
0,75\end{array}$ & $\begin{array}{l}\text { Ss }= \\
0,1\end{array}$ & $\begin{array}{l}\text { Ss } \geq \\
1,25\end{array}$ \\
\hline A & 0,8 & 0,8 & 0,8 & 0,8 & 0,8 \\
\hline B & 1,0 & 1,0 & 1,0 & 1,0 & 1,0 \\
\hline $\mathrm{C}$ & 1,2 & 1,2 & 1,1 & 1,0 & 1,0 \\
\hline $\bar{D}$ & 1,6 & 1,4 & 1,2 & 1,1 & 1,0 \\
\hline $\mathrm{E}$ & 2,5 & 1,7 & 1,2 & 0,9 & 0,9 \\
\hline F & \multicolumn{5}{|c|}{ See the provisions of article 6.10 .1} \\
\hline
\end{tabular}

Table 6. Site coefficient, $F_{v}[4]$

\begin{tabular}{|c|c|c|c|c|c|}
\hline \multirow[t]{2}{*}{$\begin{array}{c}\text { Site } \\
\text { Clas sification }\end{array}$} & \multicolumn{5}{|c|}{$\begin{array}{l}\text { Parameter Spectral Response Acceleration } \\
\qquad \mathrm{MCE}_{\mathrm{R}} \text { Earthquake in period } 1 \mathrm{~s}\end{array}$} \\
\hline & $\begin{array}{c}\text { Ss } \leq \\
0,1\end{array}$ & $\begin{array}{l}\mathrm{S}_{s}= \\
0,2\end{array}$ & $\begin{array}{l}\text { Ss= } \\
0,3\end{array}$ & $\begin{array}{l}\mathrm{S}_{s}= \\
0,4\end{array}$ & $\begin{array}{l}\text { Ss } \geq \\
0,5 \\
\end{array}$ \\
\hline A & 0,8 & 0,8 & 0,8 & 0,8 & 0.8 \\
\hline B & 1,0 & 1,0 & 1,0 & 1,0 & 1,0 \\
\hline $\mathrm{C}$ & 1,7 & 1,6 & 1,5 & 1,4 & 1,3 \\
\hline $\mathrm{D}$ & 2,4 & 2,0 & 1,8 & 1,6 & 1,5 \\
\hline $\bar{E}$ & 3,5 & 3,2 & 2,8 & 2,4 & 2,4 \\
\hline$F$ & \multicolumn{5}{|c|}{ See the provisions of article 6.10 .1} \\
\hline
\end{tabular}

\subsection{Determining Mapped Soil Motion Acceleration $S s$ and $S_{1}$}

After determining the classification of the site, the aceleration of ground motion in shorter periods $(0.2 \mathrm{secs}), S_{s}$ and $1.0 \mathrm{sec}$ period, $S_{I}$ is determined as seen on the maps in Figs. 3 and 4, respectively.

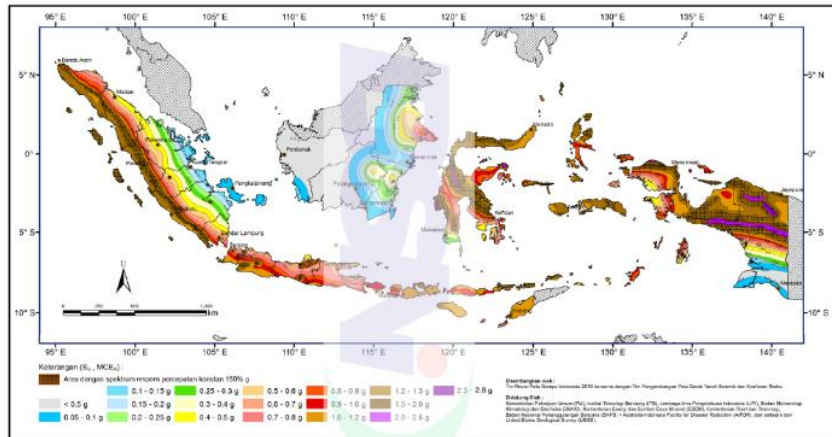

Figure 3. Map for $S_{S}$

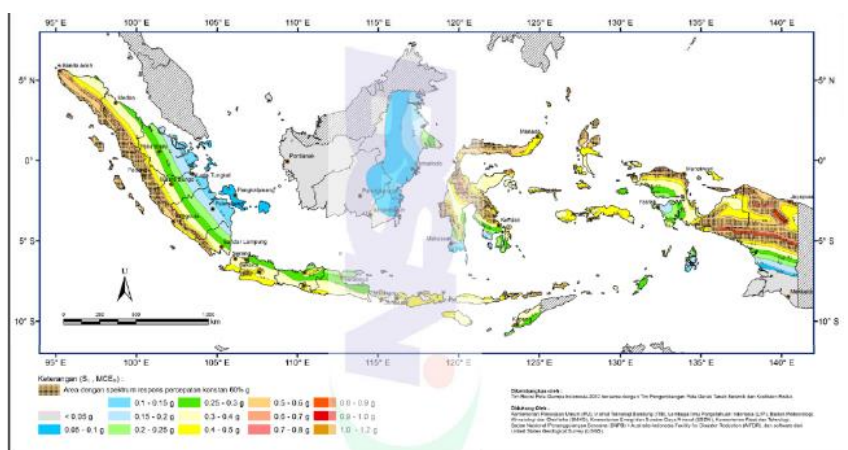

Figure 4. Map for $S_{1}$

\subsection{Determining Design Spectra Acceleration, $S_{D S}$ and $S_{D 1}$}

Prior to determining spectra of the design acceleration, parameters of acceleration response spectrum is determined by applying eqs. (1) and (2). Then the spectra of design acceleration is determined using eqs. (3) and (4). 


$$
\begin{aligned}
& S_{M S}=F_{a} \times S_{S} \\
& S_{M 1}=F_{v} \times S_{1} \\
& S_{D S}=\frac{2}{3} S_{M S} \\
& S_{D 1}=\frac{2}{3} S_{M 1}
\end{aligned}
$$

where:

$S_{M S}:$ parameter of response spectrum acceleration for short period

$S_{M 1}:$ parameters of response spectrum acceleration for 1 second period

$F_{a}$ and $F_{v}$ : sites coefficients

$S_{S}: \quad$ short period $(0.2 \mathrm{secs})$

$S_{I}: 1.0 \mathrm{sec}$ period

$S_{D S}:$ acceleration of spectra design for short period

$S_{D 1}$ : acceleration of spectra design for 1.0 sec period

\subsection{Determining the Fundamental Period Estima- tion, $T_{a}$}

As fundamental period of a structure has not been determined, fundamental period estimation, $T_{a}$, is first established. This $T_{a}$ value can be determined by eq. (5):

$$
T_{a}=C_{t} \times h_{n}^{x}
$$

where :

$T_{a}$ : fundamental period forecast

$C_{t}$ : vibrating time coefficient

$h_{n}$ : structure height from the base to the structure level.

\begin{tabular}{|c|c|c|}
\hline Type of Structure & $c_{t}$ & $x$ \\
\hline $\begin{array}{l}\text { The skeletal system bearers moment in order to } \\
\text { withstand seismic forces of } 100 \% \text { is required and is not } \\
\text { covered by or as sociated with a more rigid component } \\
\text { and would prevent order and deflection when subjected } \\
\text { to seismic forces: }\end{array}$ & & \\
\hline The steel frame bearers moment & 0,0724 & 0,8 \\
\hline Concrete frame bearers moment & 0,0466 & 0,9 \\
\hline Steel frame with eccentrically bresing & 0,0731 & 0,75 \\
\hline Steel frame with bresing restrained against buckling & 0,0731 & 0,75 \\
\hline All other structural system & 0,0488 & 0,75 \\
\hline
\end{tabular}

Table 7 below contains the vibrating time coefficient, $C_{t}$ and the estimated value of $x$.

Table 7. Vibrating time coefficient $C_{t}$ and the estimated value of $x$. [4]

\subsection{Determining Response Spectrum, $S_{a}$}

There are three provisions in determining $t$ spectrum response, as categorized in the following:
1. For the period less than $T_{0}$, the response spectrum is determined by the equation:

$S_{a}=S_{D S}\left(0.4+0.6 \frac{T}{T_{0}}\right)$

2. For a period greater than or equal to $T_{0}$ and less than

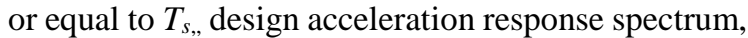
$S_{a}$, is equal to $S_{D S}$

3. For a period greater than $T_{s}$,design acceleration response spectrum, $S_{a}$, is determined by the equation:

$$
S_{a}=\frac{S_{D 1}}{T}
$$

where $T$ is the structure fundamental period. Whereas $T_{0}$ and $T_{s}$ may be determined using the following equations:

$$
\begin{aligned}
& T_{0}=0,2 \frac{S_{D 1}}{S_{D S}} \\
& T_{S}=\frac{S_{D 1}}{S_{D S}}
\end{aligned}
$$

\subsection{Determining Response Modification Coefficient, $R$}

The value of response modification coefficient, $R$, depends on the way the structure system is planned. Response modification coefficient table for a structure, whether or not that resembles a building, may refer to SNI-1726:2012 [4] in Table 9 and 20 (for the structures that resemble buildings) and Table 21 (for structures that do not resemble building).

\subsection{Determining the Seismic Response Coefficient, $C_{s}$}

Seismic response coefficient, $C_{s}$, is given by eq. (10):

$$
C_{s}=S_{D S} /\left(R / I_{e}\right)
$$

where $I_{e}$ is factors of risk categories. In this purposes the period of the structure $T$ may be approximated as the fundamental period, $T_{a}$.

\subsection{Determining Seismic Effective Weight, $W$}

Seismic effective weight, $W$, should be taken to include dead load and other loads as listed in SNI-1726:2012 article 7.2.2. Further for the value of the wind load can refer to SNI1727:2013 [5].

\subsection{Determining Basic Shear Force, $V$}

Basic shear force, $V$, is determined by multiplying seismic response coefficient with effective seismic weight as expressed in the following equation:

$V=C_{s} \times W$

Furthermore, after analyzing the equivalent lateral force, 
earthquake loads is obtained, seismic analysis was carried out by raising the burden of the PGA with maximum load of PGA according to the analysis result of the equivalent lateral force. Seismic analysis was performed by using structural analysis software.

The final stage of this final project is to analyze pushover to obtain the value of RSR (Reserve Strength Ratio). Pushover analysis was performed by using structural analysis software.

\subsection{Reserve Strength Ratio (RSR) and System Redundancy (SR)}

Jacket structure has different Reserve Strength Ratio (RSR) for each direction of loading. RSR is defined as the ratio of ultimate lateral load on its structure bridge receives environmental condition of lateral load of 100 years. This is calculated by using the procedure recommended by API RP 2A WSD [6]. RSR can be calculated by using the equation:

$$
\mathrm{RSR}=\frac{\text { Base Shear Collapse }}{\text { Base Shear Awal }}
$$

System Redundancy (SR) is the ratio of the load when structure collapse with the loads at the first event of member failure [4,7-9].

\section{RESULTS AND DISCUSSION}

\subsection{Equivalent Lateral Force Analysis}

Risk Category and Earthquake Virtue Factor, $I_{e}$. Based on the risk category in Table 2 , the jacket structure so evaluated belongs to category IV. Thus, by referring to Table 3 , the value of the earthquake virtue factor, $I_{e}$, is 1.50 .

Site Classification and Site Coefficient, $F_{a} \& F_{v}$. Based on the soil data obtained, there is only information of strong undrained shear average. Thus, site classification is determined by the undrained shear strength average contained on the soil data. Based on Table 4, the classification of the corresponding site is SB (bedrock). Hence, according to Table 5, the value of the site coefficient $F_{a}$ and $F_{v}$ is found to be 1.00 .

Acceleration of Mapped Soil Motion, $S_{s}$ and $S_{l}$. Based on the map in Figs. 3 and 4, $S_{S}$ is 0.612 and $S_{I}$ is 0.249 .

Acceleration of Design Spectra, $S_{D S}$ and $S_{D 1}$. After determining site coefficient and mapped earthquake aceleration, the next step is to determine $S_{M S}$ and $S_{M 1}$, as shown in eqs. (1) and (2). Both factors are used to determine the design acceleration spectra as in eqs. (3) and (4).

$$
\begin{aligned}
& S_{M S}=1.00 \times 0.612=0.612 \\
& S_{M 1}=1.00 \times 0.249=0.249 \\
& S_{D S}=0.67 \times 0.612=0.408 \\
& S_{D 1}=0.67 \times 0.249=0.166
\end{aligned}
$$

Fundamental Period of Estimates Structure, $T_{a}$. According to Table 7 , the type of structure is a steel frame with eccentric bracing, thus vibrate time coefficient, $C_{t}$ is 0.0731 and $x$ is 0.75 . While the height of overall jacket structure, from the mudline to helideck, is $36.016 \mathrm{~m}$. Therefore the estimated fundamental period of the structure is:

$T_{a}=0.0731 \times 36.016^{0.75}=1.075 \mathrm{secs}$

Response Spectrum, $S_{a}$. Unknown period of fundamental structural estimate is more than $T_{s}=0.407 \mathrm{secs}$, the response spectrum is determined by using the eq. (7). The trend of response spectrum, $S_{a}=\frac{S_{D 1}}{T}$, as function of time $T$ can be plotted as in Fig. 6.

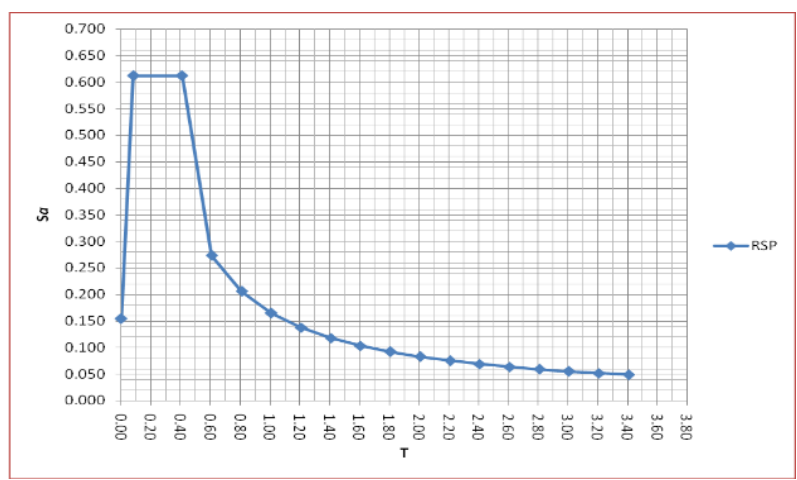

Figure 6. Response spectrum

Response Modification Coefficient, $R$ and Seismic Response Coefficient, $C_{s}$. According to Table 9 in SNI1726:2012, for system of steel frame structure with eccentric bracing, response modification coefficient, $R=8.0 . S_{D S}$ is 0.408 , the value of $I_{e}$ is 1.50 and $T=T_{a}=1.075 \mathrm{secs}$. Thus seismic response coefficient, $C_{s}$ can be determined as:

$C_{s}=0.408 /(8.0 / 1.5)=0.076$

Thus, the seismic response coefficient, $C_{s}$ is 0.076 .

Seismic Effective Weight, W. Effective seismic weight is determined by adding up all the dead loads of the overall operation load. Note that the total value of the dead load is $2,627.5$ ton and overall operating load is 893.2 ton. Then:

$W=(2,627.5+893.2)$ ton $=3,520.7$ ton

Thus, effective seismic weight, $W$ is 3,520.7 ton.

Base Shear Force, $V$. Seismic response coefficient $C_{s}$ is 0.076 and effective seismic weight $\mathrm{W}$ is 3,520.7 ton. Then the base shear force can be determined by:

$V=0.076 \times 3,520.7=267.6$ ton $=2,666.7 \mathrm{kN}$

Hence, the basic shear force, $V$ is $2,666.7 \mathrm{kN}$ or PGA $0.2 \mathrm{~g}$.

\subsection{Seismic Analysis}

This analysis aims at obtaining the response of the structure 
dynamic. Earthquake loads (PGA) used were $0.04 \mathrm{~g}, 0.08 \mathrm{~g}$, $0.12 \mathrm{~g}, 0.16 \mathrm{~g}$, and the largest was $0.2 \mathrm{~g}$ (based on the calculation of equivalent lateral force analysis).

Natural Period. The resulting natural period of seismic analysis is 1.256 secs.

Base Shear. Table 8 below contains the values of base shear generated for two orthogonal axes.

Table 8. Base shear

\begin{tabular}{|c|c|c|}
\hline \multirow{2}{*}{ PGA (g) } & \multicolumn{2}{|c|}{ Base Shear (kips) } \\
\cline { 2 - 3 } & X-Direction & Y-Diretion \\
\hline 0,04 & 19,4 & 21,6 \\
\hline 0,08 & 31,5 & 35,1 \\
\hline 0,12 & 43,6 & 48,7 \\
\hline 0,16 & 55,7 & 62,2 \\
\hline 0,2 & 67,9 & 75,7 \\
\hline
\end{tabular}

Values in Table 8 indicates that the largest base shear occurs in structures for PGA seismic load of $0.2 \mathrm{~g}$, namely 67.9 kips in the $\mathrm{X}$-direction and $75.7 \mathrm{kips}$ in the $\mathrm{Y}$-direction.

Member Check. Member check has been carried out on the structure components which are considered critical, where the results are presented in Tables 9a-c.

Table 9a. UC member group PLB

\begin{tabular}{|c|c|c|c|}
\hline PGA (g) & Member Group & Member ID & UC \\
\hline 0,04 & PLB & $301 \mathrm{~L}-201 \mathrm{P}$ & 0.27 \\
\hline 0,08 & PLB & $301 \mathrm{~L}-201 \mathrm{P}$ & 0.28 \\
\hline 0,12 & PLB & $301 \mathrm{~L}-201 \mathrm{P}$ & 0.29 \\
\hline 0,16 & PLB & $301 \mathrm{~L}-201 \mathrm{P}$ & 0.31 \\
\hline 0.2 & PLB & $301 \mathrm{~L}-201 \mathrm{P}$ & 0.34 \\
\hline
\end{tabular}

Table 9b. UC member group PLV

\begin{tabular}{|c|c|c|c|}
\hline PGA (g) & Member Group & Member ID & UC \\
\hline 0,04 & PLV & $303 \mathrm{~L}-203 \mathrm{P}$ & 0.24 \\
\hline 0,08 & PLV & $303 \mathrm{~L}-203 \mathrm{P}$ & 0.26 \\
\hline 0,12 & PLV & $303 \mathrm{~L}-203 \mathrm{P}$ & 0.29 \\
\hline 0,16 & PLV & $303 \mathrm{~L}-203 \mathrm{P}$ & 0.31 \\
\hline 0.2 & PLV & $303 \mathrm{~L}-203 \mathrm{P}$ & 0.34 \\
\hline
\end{tabular}

Table 9c. UC member group WD2

\begin{tabular}{|c|c|c|c|}
\hline PGA (g) & Member Group & Member ID & UC \\
\hline 0,04 & WD2 & $0363-0367$ & 0.87 \\
\hline 0,08 & WD2 & $0363-0367$ & 0.90 \\
\hline 0,12 & WD2 & $0363-0367$ & 0.93 \\
\hline 0,16 & WD2 & $0363-0367$ & 0.95 \\
\hline 0,2 & WD2 & $0363-0367$ & 0.98 \\
\hline
\end{tabular}

From the above three tables, it is obvious that the greater the PGA (g) yields the greater the UC member. This is because the increasing magnitude of load that occurs on the members. The fact indicates that the most critical member happen to be the member group WD2, which is the mezzanine deck of the wellhead, with UC of 0.98 and PGA of $0.2 \mathrm{~g}$.

Joint Check. The results of T-joint check, as exhibited in Table 10, indicates that the all the critical joints met the criteria according to API RP2A WSD [6], with UC below 1.0. In the Table 10, a number of maximum joint UCs are given as function of the PGA increment.
Table 10. UC of critical joints

\begin{tabular}{|c|c|c|}
\hline PGA & Joint & UC \\
\hline 0,04 & $301 \mathrm{~L}$ & 0,157 \\
\hline 0,08 & $301 \mathrm{~L}$ & 0,216 \\
\hline 0,12 & $303 \mathrm{~L}$ & 0,278 \\
\hline 0,16 & $303 \mathrm{~L}$ & 0,342 \\
\hline 0,2 & $401 \mathrm{~L}$ & 0,415 \\
\hline
\end{tabular}

\subsection{Pushover Analysis}

Pushover analysis was carried out by referring to API RP2A WSD standard code [6]. In this analysis, member on the pile is regarded as elastic member, while the others are considered as plastic member. The strength capacity of the member will be judged in accordance to the RSR and SR values.

RSR is the result of the calculation of the ratio between base shear collapse and initial base shear. Meanwhile, SR is the result of the calculation of the ratio between base shear collapse and base shear when the member experienced fail for the first time. Table 11 below gives the RSR and SR resulting from the pushover analysis with the PGA of $0.2 \mathrm{~g}$.

Table 11. Results of pushover analysis

\begin{tabular}{|c|c|c|c|c|c|c|}
\hline \multirow{2}{*}{ PGA (g) } & \multirow{2}{*}{ Load Direction } & \multicolumn{3}{|c|}{ Base Shear } & \multirow{2}{*}{ RSR } & \multirow{2}{*}{ SR } \\
\hline & & Early & 1 member failure & collapse & & \\
\hline \multirow{12}{*}{0.2} & 0 & 135.19 & 164.71 & 252.13 & 1.865 & 1.531 \\
\hline & 30 & 130.22 & 172.46 & 249.64 & 1.917 & 1.448 \\
\hline & 60 & 123.99 & 238.25 & 275.83 & 2.225 & 1.158 \\
\hline & 90 & 117.87 & 221.28 & 249.31 & 2.115 & 1.127 \\
\hline & 120 & 116.37 & 221.20 & 264.72 & 2.275 & 1.197 \\
\hline & 150 & 118.16 & 225.03 & 238.83 & 2.021 & 1.061 \\
\hline & 180 & 125.26 & 175.87 & 220.42 & 1.760 & 1.253 \\
\hline & 210 & 122.52 & 240.27 & 270.16 & 2.205 & 1.124 \\
\hline & 240 & 121.73 & 243.65 & 274.52 & 2.255 & 1.127 \\
\hline & 270 & 123.96 & 309.96 & 363.19 & 2.930 & 1.172 \\
\hline & 300 & 126.52 & 251.82 & 289.91 & 2.291 & 1.151 \\
\hline & 330 & 130.74 & 163.30 & 226.80 & 1.735 & 1.389 \\
\hline
\end{tabular}

The values in Table 11 show that the smallest RSR is at PGA $0.2 \mathrm{~g}$ with the loading direction of $330^{\circ}$, in the order of 1.735. This value proves the structure satisfy the limiting criteria according to API RP 2A WSD, and as RSR $\geq 0.8$ hence the structure is within the Low Consequence category. Further, results of the pushover analysis can be observed from the chart in Fig. 7, where comparison is made between the RSR which is predicted to occur on the platform and the allowable RSR.

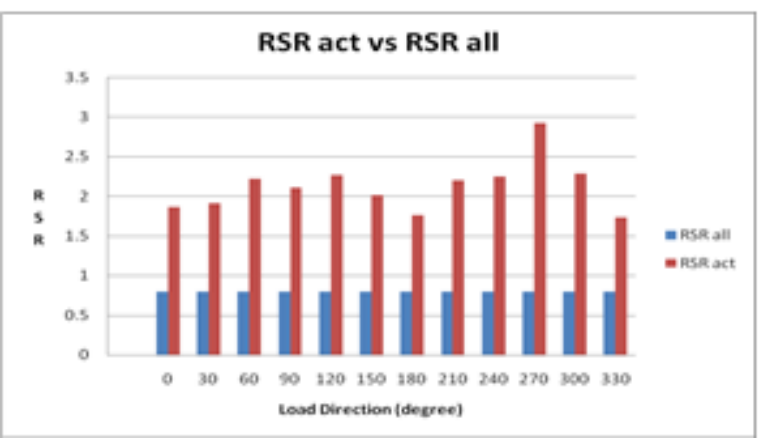

Figure 7. Comparison between predicted (actual) RSR and the allowable RSR 


\section{CONCLUSIONS}

Based on the analysis performed in this study, the following conclusions are drawn:

- Design of earthquake loads on ULA jacket platform structure with large seismic acceleration is determined by using SNI-1726:2012 standards.

- The results of seismic analysis revealed dynamic response that occurs on ULA jacket platform with 1.256 secs structure natural period. The largest base shear in $\mathrm{X}$ - and Y-directions is caused by PGA seismic acceleration of $0.2 \mathrm{~g}$.

- Based on the member check, the critical member is found to be the group WD2. Whereas on the joint check, the largest UC occurred on 401L.

- ULA jacket platform analysis resulted in RSR (Reserve Strength Ratio) which far exceeds the API RP 2A WSD criteria of RSR $\geq 0.8$. Therefore the structure is within the Low Consequence category.

\section{ACKNOWLEDGEMENTS}

The authors convey sincere gratitude to PT. ZEE Indonesia for providing technical data and to the Department of Ocean Engineering ITS for supporting the study.

\section{REFERENCES}

1. Hastanto, E.S: Analisa ultimate strength struktur jacket LE berbasis keandalan. Final Project, Jurusan Teknik Kelautan, FTK-ITS, Surabaya
2. Soegiono: Teknologi Produksi dan Perawatan Bangunan Laut. Penertbit Airlangga, Surabaya

3. Murtedjo, M., Djatmiko, E.B. and Sudjianto, H.: The influence of buoyancy parameters on the dynamic behavior of articulated tower. Jurnal Mekanikal, UTM, No. 19, pp. 32-47, June 2005

4. BSN: Tata Cara Perencanaan Ketahanan Gempa untuk Struktur Bangunan Gedung dan Non Gedung, SNI-1726:2012, Badan Standarisasi Nasional, Jakarta, 2012

5. BSN: Beban Minimum untuk Perancangan Bangunan Gedung dan Struktur Lain, SNI-1727:2013, Badan Standarisasi Nasional, Jakarta, 2013

6. API: Recommended Practice for Planning, Designing, and Constructing Fixed Offshore Platforms - Working Stress Design, (API RP 2A WSD), $21^{\text {st }}$ Ed. American Petroleum Institute, Washington D.C.

7. Health and Safety Executive: Target Levels for Reliability-Based Assessment of Structure during Design and Operation, Norwich, 1999

8. Rosyid, D.M. and Caldwell, J.B.: Design approach and dimensional similarity in lay-out optimization of structural systems. Computers \& Structures, 40 (5), pp. 1125-1137, Jan. 1999

9. Wisudawan, A., Rosyid, D.M. and Baihaqie, M.: Reliability Analysis of APN-A Offshore Jacket Using Monte Carlo Finite Element Method. Applied Mechanics and Materials, V862, pp. 259-264, 2017 